\title{
SISTEM MONITORING DAN EVALUASI KEGIATAN BELAJAR MENGAJAR (E-MONEV KBM) BERBASIS WEB
}

\author{
Sahmad ${ }^{1)}$,Tomy Dwi Cahyono ${ }^{2)}$, M.Julkarnain ${ }^{3)}$. \\ ${ }^{1)}$ Mahasiswa Informatika Universitas Teknologi Sumbawa \\ ${ }^{2)}$ Dosen Informatika Universitas Teknologi Sumbawa \\ ${ }^{3)}$ Dosen Informatika Universitas Teknologi Sumbawa
}

Email: $\underline{\text { sahmadjoe@gmail.com }}{ }^{1} \underline{\text { tomy.dwi.cahyono@uts.ac.id }}^{2}, \underline{\text { m.julkarnain@ } @ \text { uts.ac.id }^{3}}$

\begin{abstract}
Abstrak
Sebagai penyelenggara kegiatan akademik yang berbasis teknologi, Universitas Teknologi Sumbawa ingin memanfaatkan teknologi sebagai penunjang utama kegiatan di kampus. Salah satu kegiatan yang membutuhkan setuhan teknologi adalah proses monitoring dan evaluasi dalam kegiatan perkuliahan. Wakil Rektor I bidang akademik selaku bagian yang mengawasi pelaksanaan perkuliahan, selama ini sistem yang dijalankan dalam melakukan monitoring perkuliahan masih tergolong manual yaitu dengan menugaskan staff untuk melakukan pengecekan kesetiap ruangan perkuliahan. Dari sistem yang berjalan dinilai kurang efisien karna membutuhkan banyak personil pengecekan menginngat banyaknya perkuliahan yang terjadi dalam satu waktu. Oleh karena itu solusi yang digunakan untuk mengatasi hal tersebut ialah dengan membuat sistem yang terkomputerisasi yang dapat memudahkan proses monitoring dan evaluasi sehingga dapat mengurangi kebutuhan personil dan wkatu yang lama. Oleh karena itu tujuan dari penelitian ini adalah membangun sistem monitoring dan evaluasi kegiatan belajar mengajar (E-monev) berbasis web. Sistem ini dikembangkan dengan menggunakan bahasa pemrograman PHP dengan menggunakan framework codeigniter dan Mysql sebaai database dan menggunakan metode waterfall dalam pengembangan aplikasi
\end{abstract}

Kata Kunci: Universitas Teknologi Sumbawa, Wakil Rektor 1, Monitoring dan Evaluasi, Waterfall,

\begin{abstract}
As an organizer of technology-based academic activities, Sumbawa University of Technology wants to utilize technology as the main support for activities on campus. One of the activities that require technological touch is the process of monitoring and evaluation in lecturing activities. Vice Chancellor I in the academic field as the part that oversees the implementation of lectures, so far the system that is carried out in monitoring lectures is still classified as manual, namely by assigning staff to check each lecture room. From the current system, it is considered inefficient because it requires a lot of checking personnel to remember the number of lectures that occur at one time. Therefore the solution used to overcome this is to create a computerized system that can facilitate the process of monitoring and evaluation so as to reduce the need for personnel and time. Therefore the aim of this research is to develop a web-based monitoring and evaluation system of teaching and learning activities (E-Monev). This system was developed using the PHP programming language by using the Codeigniter and Mysql framework as a database and using the waterfall method in application development
\end{abstract}

Keywords: Sumbawa University of Technology, . Vice Chancellor I, Monitoring and Evaluation System, Waterfall,

\section{PENDAHULUAN}

Peran dan dukungan teknologi dalam segala bentuk proses kegiatan atau aktivitas perlu dimaksimalkan guna mempermudah dan memperlancar jalannya rutinitas sehari-hari maupun dalam dunia kerja. Efektivitas dari sebuah pekerjaan amat sangat diperlukan karena mengingat padatnya jadwal maupun pekerjaan yang lain yang tidak bisa ditinggalkan, oleh karena hal tersebut dibutuhkan sebuah alat penunjang yang dapat mendukung tercapainya kinerja yang efektif. Universitas Teknologi Sumbawa merupakan salah satu perguruan tinggi yang berada di pulau Sumbawa. Sebagai salah satu perguruan tinggi teknologi tentunya Universitas Teknologi Sumbawa menginginkan setiap aktiviats yang ada dikampus bisa terintegrasi dengan perkembangan teknologi. Monitoring kegiatan belajar mengajar di UTS selama ini masih dilakukan secara manual yaitu dengan cara menugaskan staff untuk melakukukan pengecekan kesetiap ruangan perkuliahan untuk memastikan apakah perkuliahan pada jam tersebut diselenggarakan atau tidak. Sistem tersebut dinilai kurang efektif dan efisien karena membutuhkan waktu dan tenaga yang lebih banyak dalam menjalankannya mengingat banyaknya kelas yang harus dikunjungi dalam satu waktu. Melihat kendala maupun permaslahan yang dihadapi maka peneliti mencoba mengangkat permasalahan tersebut untuk dijadikan tugas akhir kuliah tingkat strata 1 di Universitas Teknologi Sumbawa dengan judul “ 
Sistem Monitoring Dan Evaluasi Kegiatan Belajar Mengajar (E-Monev) Di Universitas Teknologi kegiatan belajar mengajar di Universitas Teknologi Sumbawa. Memastikan proses perkuliahan dilaksanakan sesuai dengan jadwal yang telah ditentukan Wakil Rektor 1 Universitas Teknologi Sumbawa. Sistem yang dibangun hanya untuk keperluan monitoring dan evaluasi kegiatan belajar mengajar di Universitas Teknologi Sumbawa.Sistem akan berjalan atau dapat diakses hanya pada jaringan lokal yang ada di kampus Universitas Teknologi Sumbawa, adapun untuk penggunaanya hanya melibatkan warek 1 dan dosen sebagai. Metode pengembangan aplikasi pada penelitian ini menggunakan metode waterfall . Sistem Monitoring dan evaluasi kegiatan belajar mengajar atau E-MONEV diharapkan mampu menjadi solusi atas permasalahan yang dihadapi oleh Wakil Rektor 1 bidang akademik dalam upaya menjaga dan mewujudkan penyelenggaraan akademik yang lebih baik, begitupun dengan hasil pengembangan aplikasi yang masih sederhana, diharapkan kedepan bisa dikembangkan menjadi sistem yang lebih kompleks dengan ditambahkannya fitur-fitur unggulan sebagai pembeda dengan yang lainnya.

\section{TINJAUAN PUSTAKA}

\section{Sistem}

Sistem adalah kumpulan dari elemen-elemen yang berinteraksi untuk mencapai suatu tujuan tertentu. sistem ini menggambarkan suatu kejadiankejadian dan kesatuan yang nyata adalah suatu objek nyata, seperti tempat, benda, dan orang-orang yang betul-betul ada dan terjadi [1].

\section{Evaluasi}

Evaluasi kinerja adalah suatu sistem evaluasi formal dari suatu organisasi yang digunakan untuk menilai kinerja individu (karyawan) dalam suatu periode tertentu yang sudah ditetapkan, (umumnya setahun sekali) dengan cara membandingkannya dengan standar kinerja yang sudah disepakati dan ditentukan lebih dahulu [2]. Evaluasi diperlukan untuk mengetahui tingkat perkembangan, kendala maupun permasalahan yang muncul ketika terselenggarakannya sebuah kegiatan, hasil dari evaluasi juga digunakan sebagai bahan pertimbangan kedepannya sehingga segala bentuk kemungkinan dapat diantisipasi.

\section{PHP}

PHP (atau resminya PHP: Hypertext Preprocessor) adalah skrip bersifat server - side yang ditambahkan ke dalam HTML.Umumnya server akan berjalan apabila ada permintaan dari client. Dalam hal ini client menggunakan kode-kode PHP untuk mengirimkan permintaan ke server [3].Sistem kerja dari PHP diawali dengan
Sumbawa“. yang bertujuan membantu efektivitas monitoring

permintaan yang berasal dari halaman website oleh browser, Selanjutnya webserver akan mencarikan berkas yang diminta dan menampilkan isinya di browser. Browser yang mendapatkan isinya segera menerjemahkan kode HTML dan menampilkannya pada halaman browser tersebut [4].PHP banyak digunakan untuk membuat halaman website dinamis, kode pada php cukup simple sehingga untuk memperbnayak halaman dalam sebuah web cukup dengan memanggil perintah dan menjalankan kode fungsi yang terdapat pada php .

\section{CodeIgniter}

CodeIgniter adalah sebuah framework yang digunakan untuk membuat sebuah aplikasi berbasis web yang disusun dengan menggunakan bahasa PHP. Di dalam CI terdapat beberapa macam kelas (class) yang berbentuk library dan helper. Keduanya berfungsi untuk membantu pemrogram (programmer) dalam mengembangkan aplikasinya [5].CodeIngiter dibuat untuk mempermudah pengembangan proyek prangkat lunak dengan memberikan fitur-fitur standar agar dalam proses pengembangan dari prangkat lunak lebih cepat tanpa harus menuliskan kode dari awal . CodeIngniter menyediakan berbagai library yang bisa digunakan untuk menyelesaikan tugas yang dibutuhkan, codeingniter juga meyediakan tampila grafis dan struktur yang logis dan sederhana untuk mengakses library ini. CodeIgniter memungkinkan pengembang terfokus pada proyek dengan meminimalkan jumlah kode yang dibutuhkan untuk tugas yang diberikan

\section{Waterfall.}

Metode air terjun atau yang sering disebut metode waterfall sering dinamakan siklus hidup klasik (classic life cycle), dimana hal ini menggambarkan pendekatan yang sistematis dan juga berurutan pada pengembangan perangkat lunak, dimulai dengan spesifikasi kebutuhan pengguna lalu berlanjut melalui tahapan-tahapan perencanaan (planning), permodelan (modeling), konstruksi (construction), serta penyerahan sistem ke para pelanggan/pengguna (deployment), yang diakhiri dengan dukungan pada perangkat lunak lengkap yang dihasilkan [6]. 




Gambar 1 Tahapan Metode Waterfall

\section{METODE PENELITIAN}

\section{Jenis Penelitian}

Penelitian yang dilakukan merupakan penelitian kualitatif, teknik pengumpulan data pada penelitian kualitatif bersifat triangulasi, yaitu menggunakan berbagai teknik pengumpulan data secara gabungan/simulta. Analisis data yang dilakukan bersifat induktif berdasarkan fakta-fakta yang ditemukan dilapangan dan kemudian dikonstruksikan menjadi hipotesis atau teori [7]. Peneliti melakukan pengambilan data melalului wawancara, observasi dan studi pustaka yang dilakukan UPT IT Universitas Teknologi Sumbawa dan wakil rektor 1 sebagai tempat memperoleh data.

\section{Metode Pengembangan Perangkat Lunak}

Metode pengembangan perangkat lunak yang digunakan adalah metode waterfall. Adapun mengenai langkah-langkah dalam metode watrfall adalah sebagai berikut :

\section{Requirement}

Requirment atau persyaratan ialah tahap pertama yang dilakukan dalam mengembangkan sebuah sistem. Persyaratan yang dimakksud adalah minimal spesifikasi pendukung baik prangkat keras maupun prangkat lunak yang dibutuhkan .Untuk mengetahui minimal persyaratn tersebut peneliti melakukan wawancara dan komunikasi secara intern kepada UPT IT dan wakil rektor 1 yang bertujuan untuk memahami sistem yang diharapkan sehingga minmal persyaratan yang dibutuhkan dalam pengembangan sistem dapat ditentukan .

2. System Design

Setelah menentukan minimal spesifikasi kebutuhan dari tahapan sebelumnya kemudian peneliti mendesain sistem yang akan diterapkan. Desain Sistem berupa penggambaran diagram alur, relasi antar tabel, gambaran tampilan dan gambaran aktivitas yang dapat dilakukan dalam sistem.

3. Implementation atau Penerapan

Pada tahap ini, sistem yang telah didesain akan diterapkan kedalam bentuk apliaksi atau dilakukan pengkodean program sehingga sistem yang dimaksud bisa dijalankan dalam bentuk aplikasi komputer
4. Testing atau Pengujian

Setelah sistem selesai diimplementasikan dalam bentuk apliaksi kemudian dilakukan pengujian untuk memastikan apakah sistem berjalan sesuai dengan yang diharapkan atau masih terjadi error atau kesalahan-keslahan lainnya.

5. Pengoprasian dan Perawatan

Tahap akhir dalam model waterfall. Perangkat lunak yang sudah jadi, dijalankan serta dilakukan pemeliharaan. Pemeliharaan termasuk dalam memperbaiki kesalahan yang tidak ditemukan pada langkah sebelumnya.

\section{Alur penelitian}

Diagram alir pada gambar dibawah ini menjelaskan tentang alur penelitian yang dilukan oleh peneliti.

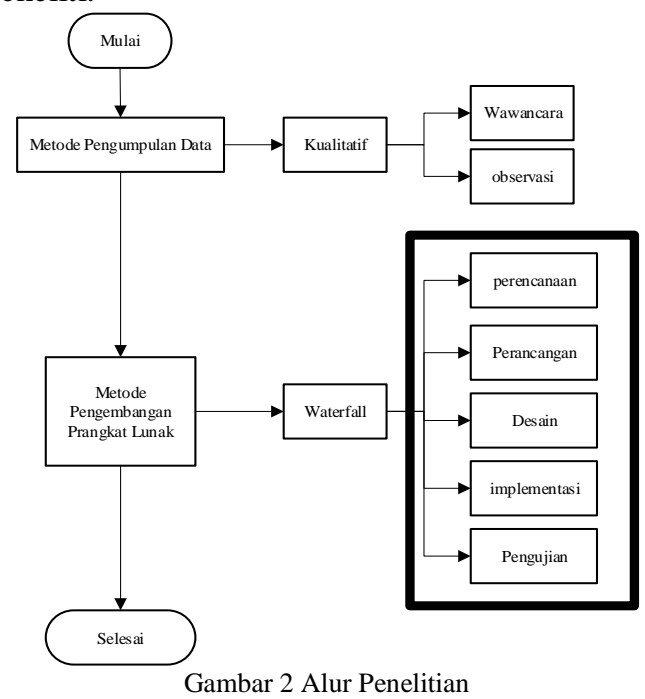

\section{HASIL DAN PEMBAHASAN}

\section{Alur kerja Sistem Usulan}

Sistem yang diinginkan dalam proses monitoring KBM adalah sistem yang terintegrasi dan terkomputerisasi. Berikut adalah diagram alur sistem yang diusulkan. 


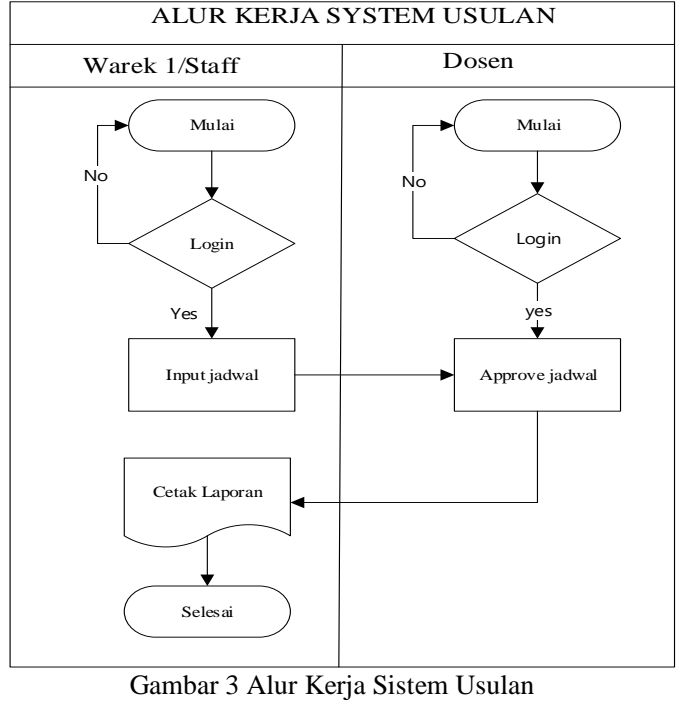

\section{Design Rancangan System}

Design sistem menggambarkan bagaimana sistem akan dibuat, alur kerja sistem, data base yang digunakan, tampilan antar muka sistem. Berikut adalah gambaran sistem yang dimuat dalam entuk diagram.

\section{Usecase Diagram}

Usecase diagram rancangan sistem monitoringf dan evaliasi seperti berikut

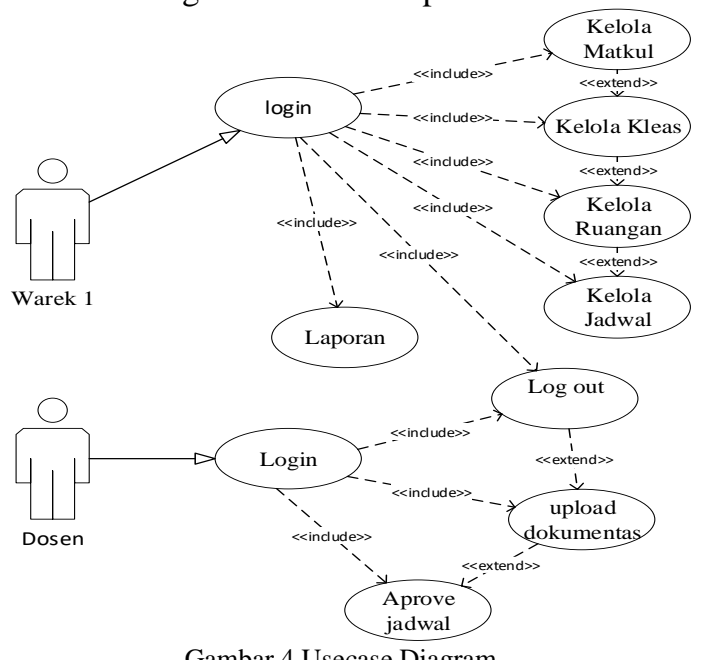

Dari diagram diatas dapat diketahui bahwa hak akses yang diberikan ke admin atau warek 1 dapat mengelola beberapa objek diantaranya adalah mengelola matakuliah, kelas, ruangan, jadwal matakuliah dan laporan berikut dengan mencetaknya kedalam hard copy.

2. Activity Diagram

Activity diagram mengambarkan bentukbentuk aktivitas maupun interaksi dengan sistem yang dapat dilakukan oleh pengguna, berikut adalah gambaran aktivitas pengguna dalam sistem E-MONEV

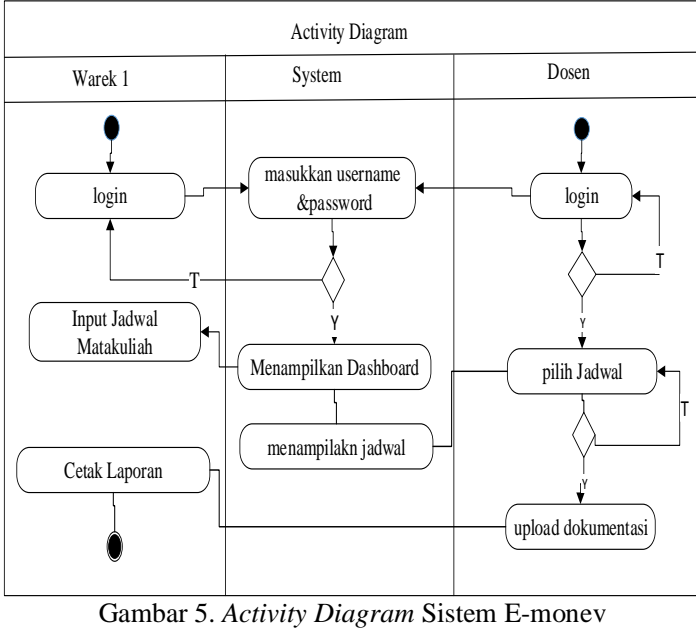

Pada aktivity diagram diatas menjelaskan bahwa interaksi antara aktor dengan sistem ketika wakil rektor 1 melakukan login kesistem maka sistem akan meminta validasi hak akses, sistem akan meminta username dan password kepada warek 1, apabila akun yang dimaksukkan valid maka sistem akan membuka akses dengan menampilkan dashboard atau halaman utama. Begitu pun dengan dosen selaku user yang menggunakan sistem ketika ingin melakukan aktivitas didalam sebuah sistem maka sistem pun akan meminta akun login sebagai bentuk validasi dari pengguna.

3. Diagram Hubungan Antar Tabel

Diagram Hubungan Antar Tabel mengambarkan hubungan antara entitas atao objek dalam sebuah tabel, berikut adalah Diagram Hubungan Antar Tabel yang dari EMONEV

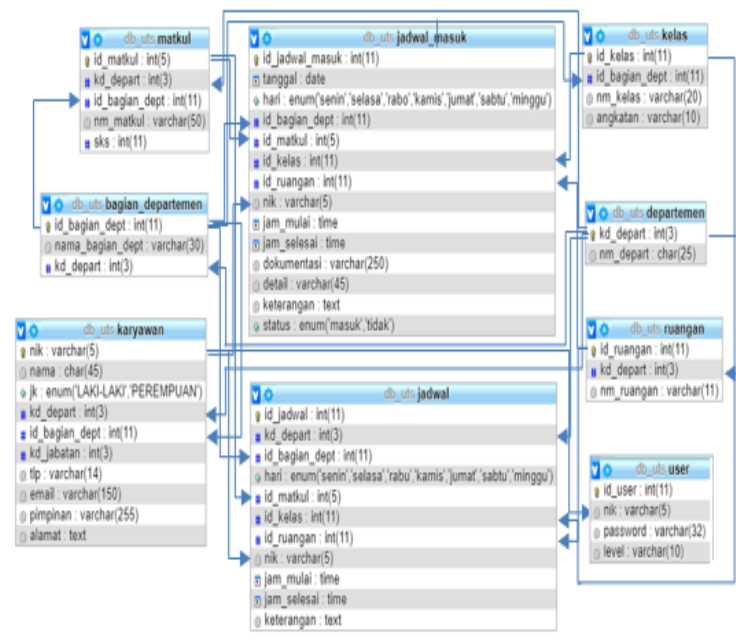

Gambar 6 Relasi Antar Tabel

Relasi antar tabel diatas dapat dijelaskan bahwa terdapat sembilan tabel yang saling berhungan yaitu tabel jadwal, tabel kelas,tabel ruangan, tabel karyawan, tabel departemen, tabel bagian departemen, tabel user tabel jadwal masuk, tabel matakuliah . dari kesembilan tabel 
diatas empat diantaranya merupakan tabel yang sudah ada pada sistem yang ada sebelumnya di UPT IT UTS yaitu tabel departemen, tabel bagian departemen, tabel user dan tabel karyawan. Sistem E-monev dirancang dengan sistem yang terintegrasi dengan sistem yang ada di UPT IT dengan tujuan agar pengguna yang
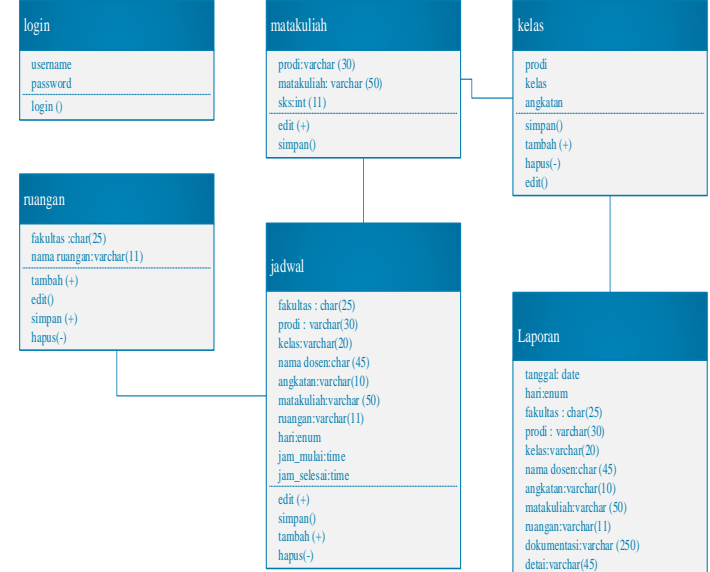

Gambar 7 Class Diagram Sistem E-MONEV

\section{Design Tampilan}

Halaman dashboard admin adalah halaman utama yang akan ditemukan oleh admin ketika telah melakukan login sistem, berikut adalah rancangan halaman dashboard untuk admin.

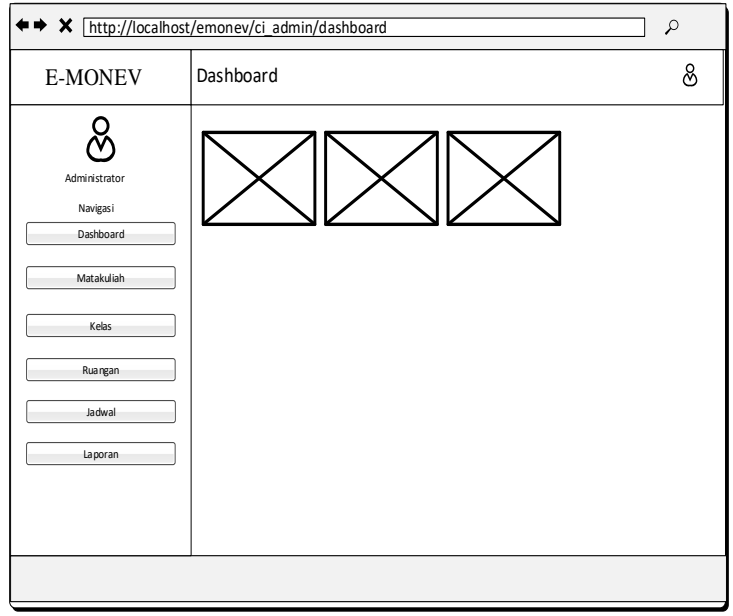

Gambar 8 Rancangan Halaman Dashboard Admin

Halaman dashboard atau halaman utama admin terdapat button navigasi dan berupa informasi singkat tentanng grafik penggunaan sistem.Button navigasi yang terdapat pada halam dashboard ialah button matakuliah, button kelas, button ruangan, button jadwal dan bautton loporan. Pada setiap terdapat menu tambah dan list daftar setiap form yang telah diisi. Pada bagian kanan atas terdapat menu untuk keluar sistem.

6. Halaman Daftar Jadwal akan menggunakan sistem E-Monev tidak lagi harus membuat akun untuk masuk menggunakan sistem.

4. Class Diagram

Class diagram mengambarkan class atau komponen-komponen yang membangun sistem E-MONEV

Tampilan untuk melihat daftar jadwal yang telah di inputkan akan di rancang seeperti pada gambar dibawah ini.

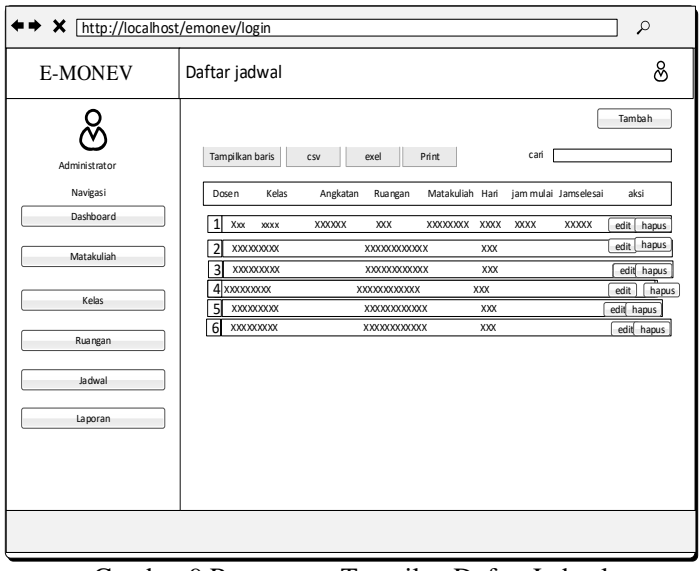

Gambar 9 Rancangan Tampilan Daftar Jadwal

7. Halaman Utama User

Adapun rancangan halaman user atau dosen yang telah login seperti pada gambar dibawah ini.

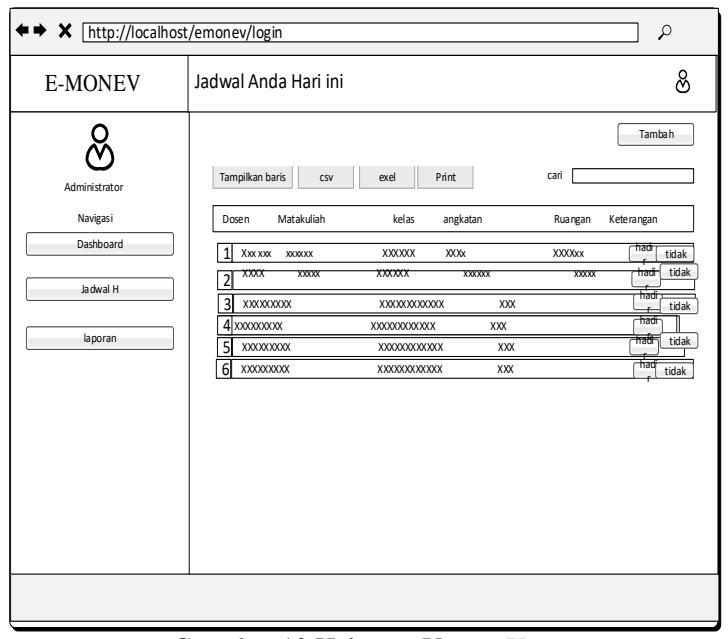

Gamabar 10 Halaman Utama User

Rancangan halaman utama untuk user akan disertakan 3 nvigasi utama yaitu dashboard Jadwal dan laporan jadwal yang telah diisi.

\section{Implentasi}

Berikut adalah tampilan untuk hasil implementasi halaman sistem 


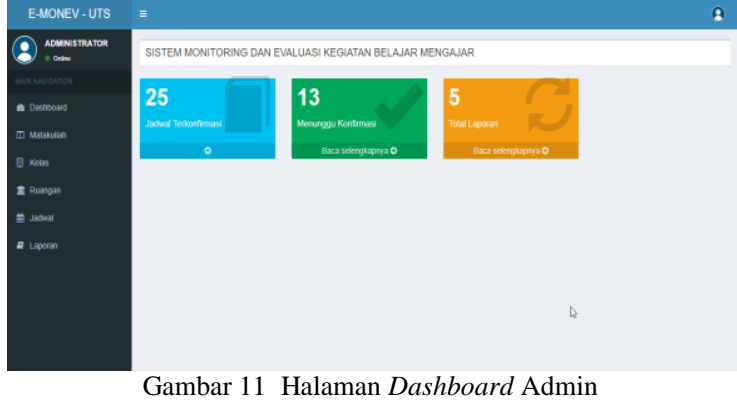

Dashboard dapat diakses setelah pengguna melakukan login dengan memasukkan akun, halaman dashboar memuat beberapa menu yang bisa langsung diakses oleh pengguna diantaran menu matakuliah, kelas, ruangan, jadwal dan laporan.

1. Halaman Daftar Jadwal

Halaman datar jadwal adalah halaman untuk menampilkan daftar jadwal yang telah diinputkan.

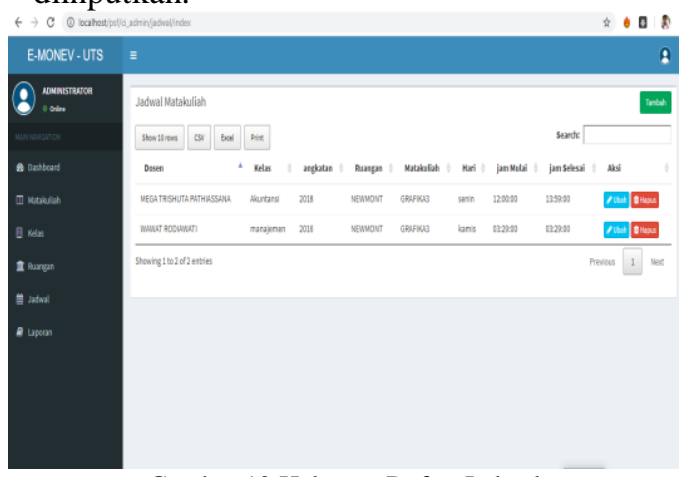

Gambar 12 Halaman Daftar Jadwal

Pada halaman daftar jadwal terdapat beberapa fungsi button yang bisa digunakan diantaranya button edit untuk merubah, button hapus untuk menghapus dan button tambah untuk menambah.

2. Halaman Jadwal

Berikut adalah implementasi halaman jadwal untuk user arau dosen.

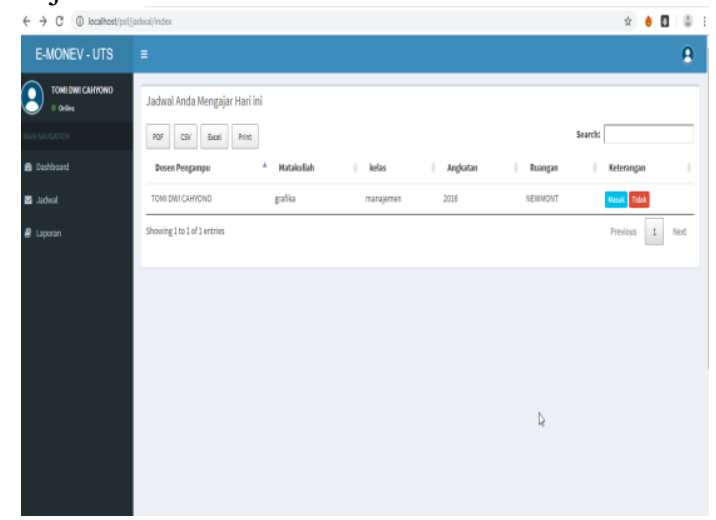

Gambar 13 Halaman Jadwal Dosen
1. Halaman Dashboard Admin

Halaman jadwal untuk dosen akan menampilkan daftar jadwal dosen yang bersangkutan pada hari tersebut. Daftar jadwal yang akan tampil akan berubah-ubah sesuai dengan hari ketika dosen melakukam login. Pada halaman jadwal ini user atau dosen dapat melakukan konfirmasi kehadiran dengan mengklik button masuk yang terdapat pada kolom keterangan.

\section{Pengujian}

Pengujian sistem menggunakan metode alfa text. Pengujian dengan alfa text digunakan untuk menemukan kesalahan pada fungsi seperti fungsi hialang atau tidak benar, kesasalahan struktur data dll. Hasil pengujian dapat dilihat pada dokumentasi teknis berikut.

Tabel 1 Pengujian Perangkat lunak 


\begin{tabular}{|c|c|c|c|}
\hline $\begin{array}{l}\text { No } \\
\text {. }\end{array}$ & $\begin{array}{c}\text { Bentuk } \\
\text { Pengujian }\end{array}$ & Tampilan Aplikasi & Data Uji \\
\hline 1 & $\begin{array}{l}\text { Pengujia } \\
\mathrm{n} \text { Login } \\
\mathrm{Ke} \\
\text { Sistem }\end{array}$ & $\begin{array}{l}\text { E-MONEV I UTS } \\
\text { Sistem MONITORING DAN EVALUASI } \\
\text { KBM } \\
\text { F-mall } \\
\text { Password } \\
\end{array}$ & $\begin{array}{l}\text { Login } \\
\text { Menggunak } \\
\text { an } \\
\text { Username } \\
\text { dan } \\
\text { Password }\end{array}$ \\
\hline 2 & $\begin{array}{l}\text { Pengujia } \\
\text { n Input } \\
\text { Jadwal }\end{array}$ & 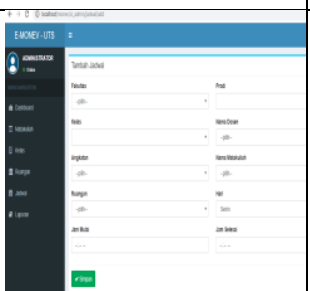 & $\begin{array}{l}\text { Input } \\
\text { Jadwal } \\
\text { dengan } \\
\text { Data yang } \\
\text { berhubunga } \\
\mathrm{n} / \\
\text { berrelasi }\end{array}$ \\
\hline 3 & $\begin{array}{l}\text { Pengujia } \\
\mathrm{n} \\
\text { menampi } \\
\text { lkan } \\
\text { jadwal } \\
\text { berdasark } \\
\text { an hari }\end{array}$ & 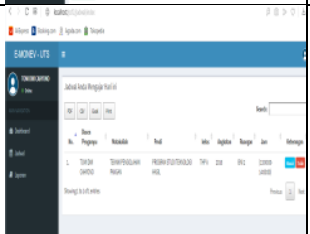 & $\begin{array}{l}\text { Data login } \\
\text { Menggunak } \\
\text { an Akun } \\
\text { masing- } \\
\text { masing } \\
\text { User }\end{array}$ \\
\hline 4 & $\begin{array}{l}\text { Pengujia } \\
\mathrm{n} \\
\text { menampi } \\
\text { lkan } \\
\text { dokumen } \\
\text { tasi foto } \\
\text { sebelum } \\
\text { di submit }\end{array}$ & $8=-$ & $\begin{array}{l}\text { Data uji } \\
\text { halaman } \\
\text { uploas } \\
\text { dokumentas } \\
\text { i }\end{array}$ \\
\hline 5 & $\begin{array}{l}\text { Pengujia } \\
\mathrm{n} \\
\text { menampi } \\
\text { lakn } \\
\text { detail } \\
\text { foto } \\
\text { dokumen } \\
\text { tasi }\end{array}$ & 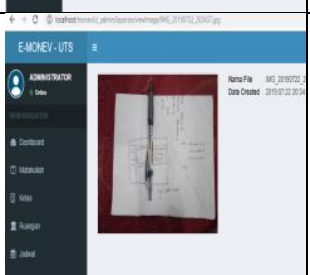 & $\begin{array}{l}\text { Data uji } \\
\text { foto yang di } \\
\text { upload }\end{array}$ \\
\hline 6 & $\begin{array}{l}\text { Pengujia } \\
\mathrm{n} \\
\text { Laporan }\end{array}$ & 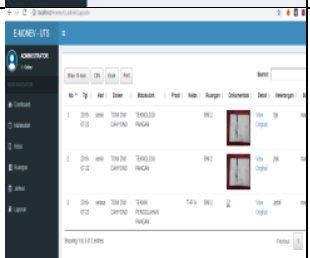 & $\begin{array}{l}\text { Data Uji } \\
\text { jadwal } \\
\text { yang Telah } \\
\text { di } \\
\text { konfirmasi } \\
\text { User }\end{array}$ \\
\hline
\end{tabular}




\section{KESIMPULAN DAN SARAN}

\section{Kesimpulan}

Berdasarkan hasil perancangan yang telah dilakukan, sistem monitorinng dan evaluasi kegiatan belajar mengajar (E-MONEV) talah berhasil dibangun menggunakan bahasa pemrograman PHP dengan framework codeigniter, data base Mysql dan Css bootstrap. Pengembangan aplikasi menggunakan metode waterfall. sistem ini dapat digunakan untuk memonitoring dan evaluasi kegiatan belajar mengajar di kampus Universitas Taknologi Sumbawa .

\section{Saran}

Diperlukan adanya pengembangan dari sistem yang telah dibangun untuk meningkatkan kompleksitas baik dari segi aktivitas dalam sistem maupun fitur yang disediakan. Fitur yang bisa ditambah ialah berupa penambahan kurikulum sehingga sistem monitoring tidak hanya untuk aktivitas belajar mengajar saja tetapi juga untuk memonitor target pencapaian materi perkuliahan.

\section{Daftar Pustaka}

[1] Jogianto HM. 2005. Sistem Teknologi Informasi. Andi. Yogyakarta.

[2] Abdullah, M. Ma'ruf. 2014. Manajemen dan Evaluasi Kinerja Karyawan. Aswaja Pressindo.Yogyakarta

[3] Kustiyahningsih, D. Rosa. 2011. Pemrograman Basis Data Berbasis WEB Menggunakan PHP dan Mysql. Graha Ilmu. Yogyakarta.

[4] Astria Firman Dkk. (2016)." Sistem Informasi Perpustakaan Online Berbasis Web." Ejournal Teknik Elektro dan Komputer, 5 (2), 29-36.

[5] Riyanto. 2011. Membuat Sendiri Aplikasi Ecommerce dengan PHP dan MySQL Menggunakan Codeigniter dan JQuery. Andi. Yogyakarta.

[6] Pressman, Roger S. 2012. Rekayasa Perangkat Lunak. Edisi 7. Diterjemahkan oleh: Adi Nugroho. Andi. Yogyakarta.

[7] Sugiyono. 2106. Metode Penelitian Kombinasi (Mixed Methods). Alfa Beta.Bandun 